\title{
Pengujian Tarik Dan Impak Pada Pengerjaan Pengelasan SMAW Dengan Mesin Genset Menggunakan Diameter Elektroda Yang Berbeda
}

\author{
M. Zaenal Mawahib ${ }^{\left.1)^{*}\right)}$, Sarjito Jokosisworo ${ }^{1)}$, Hartono Yudo ${ }^{1)}$ \\ ${ }^{1)}$ Departemen Teknik Perkapalan, Fakultas Teknik, Universitas Diponegoro \\ Jl. Prof. Soedarto, SH, Kampus Undip Tembalang, Semarang, Indonesia 50275
}

\begin{abstract}
Abstrak
Pengaruh hasil sumber daya listrik yang dihasilkan dari mesin genset yaitu kemungkinan terjadinya lubang cacing dan retak, dan apabila arus yang terlalu rendah akan mengakibatkan kurangnya penembusan dan kemungkinan terak terperangkap tinggi, sehingga dapat mengakibatkan kekuatan dari sambungan lasan yang rendah. Pengujian pada sambungan pengelasan yang berbeda diameter elektroda dengan menggunakan mesin genset, akan diperoleh kekuatan tarik dan kekuatan impak maksimum dari masing-masing material uji dan dapat diketahui pemilihan diameter elektroda yang paling baik digunakan untuk masing-masing pelat. Pengelasan menggunakan jenis sambungan butt joint (single V-groove) dengan sudut $60^{\circ}$, dengan diameter elektroda 3,2 mm dan $4 \mathrm{~mm}$ dengan tebal masing-masing material uji $8 \mathrm{~mm}$ dan $10 \mathrm{~mm}$. Hasil pengujian didapatkan kuat tarik dari diameter elektroda 3,2 mm tebal material 8 $\mathrm{mm}$ adalah rata-rata 443,747 N/ $\mathrm{mm}^{2}$, diameter elektroda 3,2 $\mathrm{mm}$ tebal material $10 \mathrm{~mm}$ adalah rata-rata 435,187 $\mathrm{N} / \mathrm{mm}^{2}$, diameter elektroda $4 \mathrm{~mm}$ tebal material $8 \mathrm{~mm}$ adalah rata-rata 447,23 N/ $\mathrm{mm}^{2}$, dan diameter elektroda $4 \mathrm{~mm}$ tebal material $10 \mathrm{~mm}$ adalah rata-rata 447,07 $\mathrm{N} / \mathrm{mm}^{2}$. Hasil penelitian, modulus elastisitas dan tegangan luluh samasama memiliki kenaikan nilai, serta nilai pada regangan menurun. Sedangkan hasil pengujian impak didapatkan energi impak dari diameter elektroda 3,2 $\mathrm{mm}$ tebal material $8 \mathrm{~mm}$ adalah rata-rata 90,67 Joule, diameter elektroda 3,2 mm tebal material $10 \mathrm{~mm}$ adalah rata-rata 295,9 Joule, diameter elektroda $4 \mathrm{~mm}$ tebal material $8 \mathrm{~mm}$ adalah rata-rata 44,91 Joule, dan diameter elektroda $4 \mathrm{~mm}$ tebal material $10 \mathrm{~mm}$ adalah rata-rata 273,83 Joule.
\end{abstract}

Copyright @ 2017, KAPAL, 1829-8370 (p), 2301-9069(e)

Kata Kunci : Mesin Genset, Pengelasan SMAW, Diameter Elektroda, Kekuatan Tarik, Kekuatan Impak

\section{PENDAHULUAN}

Dalam pengelasan las listrik menggunakan energi listrik yang dihasilkan dari mesin genset akan mempengaruhi hasil lasan karena naik turunnya tegangan voltase. Voltase harus disesuaikan dengan bahan material yang akan dilas termasuk pemilihan kawat elektroda yang sesuai. Sambungan las tumpul atau butt joint adalah sambungan yang paling sering ditemui di kapal, umumnya pelat yang digunakan memiliki tebal yang sama.

Sedangkan dalam proses pengelasan, kawat elektroda merupakan salah satu bagian penting dalam menentukan kualitas hasil pengelasan.

*) Penulis Korespondensi :

Email : m.zaenal.mawahib.15@gmail.com
Adapun pengaruh hasil pengelasan yang kemungkinan terjadinya lubang cacing dan retak yang tinggi dan apabila kuat arus yang terlalu rendah akan mengakibatkan kurangnya penembusan dan kemungkinan terak terperangkap tinggi.

Oleh karena itu perlu adanya pemilihan kuat arus dan voltase yang baik untuk hasil pengelasan yang maksimal dalam menggunakan mesin genset. Penulis akan meneliti kekuatan tarik dan kekuatan impak pada sambungan butt joint dengan perbedaan diameter elektroda ditinjau dari ketebalan pelat yang sama pula pada masingmasing pengelasan. Penelitian ini juga merupakan lanjutan dari penelitian sebelumnya yang membahas kekuatan tarik pelat dengan perbedaan arus pada pengelasan. Adapun tujuan dari 
penelitian ini adalah untuk membandingkan hasil kekuatan tarik dari pengerjaan pengelasan SMAW dengan mesin genset pada dua jenis elektroda yang berbeda diameternya dan juga untuk membandingkan hasil kekuatan impak dari pengerjaan pengelasan SMAW dengan mesin genset pada dua jenis elektroda yang berbeda diameternya.

\section{METODE}

\subsection{Pengelasan SMAW}

Proses las SMAW terdiri dari pembungkus elektroda, sumbu kawat, daerah sekitar busur (arc), gas perisai, logam yang diendapkan dan terak (slag) yang telah mengeras. Proses las listrik atau pengelasan SMAW merupakan suatu proses las manual, dapat dikendalikan oleh tangan dan sangat praktis. Proses las listrik ini dapat digunakan untuk mengelas semua jenis bangunan logam dari yang tipis sampai yang tebal dengan pengelasan sistem single pass atau multi pass.

Untuk las biasa mutu lasan antara harus searah dengan arus bolak-balik tidak jauh berbeda, namun polaritas sangat mempengaruhi mutu pengelasan. Kecepatan pengelasan dan keserbagunaan mesin las arus bolak-balik dan arus searah hampir sama, namun untuk pengelasan logam tebal, las arus bolak-balik lebih tepat.

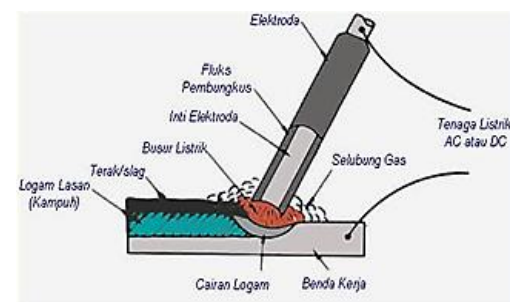

Gambar 1. Proses Pengelasan SMAW

\subsection{Besar Arus Las}

Arus pengelasan adalah aliran pembawa muatan listrik dari mesin las yang digunakan untuk menyambung dua logam dengan mengalirkan panas ke logam pengisi atau elektroda. Hubungan diameter elektroda dengan arus pengelasan menurut Dendi Abdulah, 2008 dapat dilihat pada Tabel 1 .

Arus las memberikan pengaruh yang terbesar pada penembusan dan penguatan. Arus yang terlalu kecil akan menghasilkan penembusan dan penguatan yang rendah dan bila terlalu besar akan menghasilkan lasan yang cacat.
Tabel 1. Hubungan Diameter Elektroda dengan Arus Pengelasan

\begin{tabular}{crrrrrr}
\hline $\begin{array}{c}\text { Diameter } \\
\text { elektroda } \\
\text { dalam mm }\end{array}$ & E 6010 & E 6014 & E 7018 & E 7024 & E 7027 & E 7028 \\
\hline 2,5 & & $80-125$ & $70-100$ & $100-145$ & & \\
3,2 & $80-120$ & $110-160$ & $115-165$ & $140-190$ & $125-185$ & $140-190$ \\
4 & $120-160$ & $150-210$ & $160-220$ & $180-260$ & $180-240$ & $180-250$ \\
5 & $160-200$ & $200-275$ & $200-275$ & $230-305$ & $210-300$ & $230-305$ \\
5,5 & & $260-340$ & $260-340$ & $275-285$ & $250-350$ & $275-365$ \\
6,3 & & $330-415$ & $315-400$ & $335-430$ & $300-420$ & $335-430$ \\
8 & & $390-500$ & $375-470$ & & & \\
\hline
\end{tabular}

\subsection{Masukan Panas}

Adalah siklus thermal las dalam proses pemanasan daerah lasan yang berfungsi untuk mengetahui masukan panas sehingga akan diketahui kekuatan dari masing-masing Ampere pada kecepatan yang berbeda, sesuai dengan Persamaan (1).

$$
H I=\frac{60 . E \cdot I}{v}
$$

dimana $\mathrm{HI}=$ masukan panas (joule $/ \mathrm{cm}$ ), $\mathrm{E}=$ tegangan busur (volt), $\mathrm{I}=$ arus las (ampere), $\mathrm{v}=$ kecepatan las (cm/menit).

\subsection{Parameter Penelitian}

1. Parameter Tetap

a. Uji tarik dengan standar ASTM E8.

b. Uji impak dengan standar ASTM E23.

c. Tipe pengelasan dengan SMAW.

d. Kecepatan pengelasan $14-15 \mathrm{~cm} /$ menit.

e. Kuat arus 150 Ampere.

f. Voltase 25 Volt.

2. Parameter Peubah

a. Diameter elektroda 3,2 $\mathrm{mm}$ dan $4 \mathrm{~mm}$.

b. Ketebalan pelat $8 \mathrm{~mm}$ dan $10 \mathrm{~mm}$.

\subsection{Persiapan Ilustrasi Pengelasan}

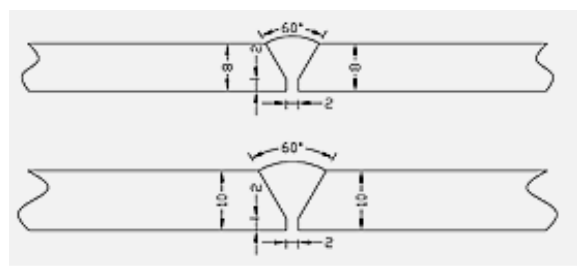

Gambar 2. Persiapan Ilustrasi Pengelasan

\subsection{Dimensi Spesimen}

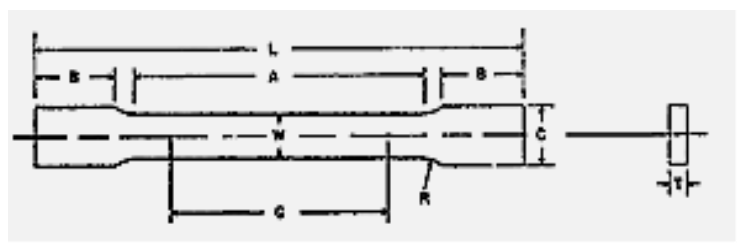


Gambar 3. Ukuran Spesimen Tarik Menurut ASTM E8

Tabel 2. Ukuran Spesimen Tarik Menurut ASTM E8

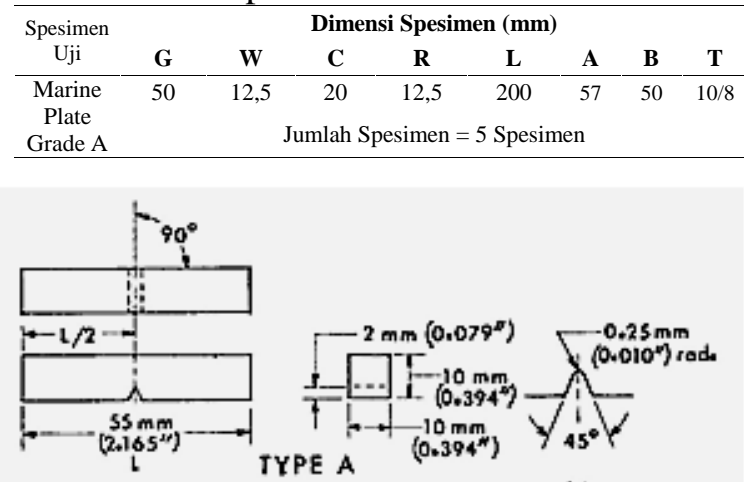

Gambar 11. Ukuran Spesimen Impak Menurut ASTM E23

\section{HASIL DAN PEMBAHASAN}

\subsection{WPS (Welding Procedure Specification)}

Sebelum pembuatan prosedur pengelasan, perlu adanya pengetahuan tentang material properti yang bertujuan untuk mengetahui sifatsifat dari material yang akan dilas. Adapun material bahan baja kapal marine plate grade $A$ adalah material yang tersedia dipasaran yang biasa digunakan untuk membangun dan mereparasi kapal.

$\frac{\text { Tabel 3. Material Properti Marine Plate Grade A }}{\text { Ultimate }}$

\begin{tabular}{cccccc}
\hline $\begin{array}{c}\text { Tipe } \\
\text { Material }\end{array}$ & $\begin{array}{c}\text { Ultimate } \\
\text { Tensile } \\
\text { Strength } \\
(\mathrm{MPa})\end{array}$ & $\begin{array}{c}\text { Yield } \\
\text { Strength } \\
(\mathrm{MPa})\end{array}$ & $\begin{array}{c}\text { Density } \\
\left(\mathrm{kg} / \mathrm{m}^{3}\right)\end{array}$ & $\begin{array}{c}\text { Elastic } \\
\text { Modulus } \\
(\mathrm{GPa})\end{array}$ & $\begin{array}{c}\text { Poisson } \\
\text { Ratio }\end{array}$ \\
\hline $\begin{array}{c}\text { Marine } \\
\text { Plate }\end{array}$ & $350-480$ & 235 & 7850 & 210 & 0.3 \\
Grade A & & & & & \\
\hline
\end{tabular}

Prosedur pengelasan merupakan suatu perencanaan untuk pelaksanaan pengelasan yang meliputi cara pembuatan konstruksi las yang sesuai dengan rencana dan spesifikasinya dengan menentukan semua hal yang diperlukan dalam pelaksanaan pengelasan. Prosedur pengelasan harus menyesuaikan dengan ketentuan-ketentuan yang berlaku agar memenuhi dari standar yang telah ditentukan.

Pembuatan prosedur pengelasan harus dibuat secara lengkap dan terperinci agar tidak terjadi kesalahan atau terjadinya cacat dalam proses pengelasan. Kurangnya informasi dalam perencanaan prosedur pengelasan mengakibatkan terjadinya kesalahan-kesalahan baik dari kesalahan welder ataupun pada proses pengelasan. Proses pengelasan mengacu kepada standar ASME Section IX dengan posisi las datar (1G) butt joint single $V$-groove $60^{\circ}$ tanpa backing. Pengelasan mengacu pada standar AWS (American Welding
Society) D1,1/D1,1 M:2004 halaman 167 figure 4.24.

Pada penelitian ini, sambungan pelat yang akan dilas tidak menggunakan backing dan tidak double weld, hanya single weld dan full penetration dengan suhu ruangan.

\subsection{Proses Pengelasan}

Pemotongan lembaran pelat menggunakan gas oxy-acetylene dengan ukuran dimensi pelat $345 \mathrm{~mm} \times 215 \mathrm{~mm}$ untuk masing-masing tebal $8 \mathrm{~mm}$ dan $10 \mathrm{~mm}$ sebanyak dua lembar pelat. Setelah pemotongan dilakukan pendinginan dengan cara didiamkan beberapa saat. Pendinginan menggunakan metode air atau bahan lainya akan mengakibatkan material mengalami deformasi yang tinggi, sehingga untuk mencegah terjadinya deformasi, material hanya didinginkan dengan didiamkan beberapa saat.

Setelah pemotongan, langkah selanjutnya adalah membuat sudut bevel. Pada penelitian ini menggunakan sudut sebesar $60^{\circ}$, pada lapisan sambungan las menggunakan sebanyak 3 lapisan las tanpa gouging balik.

Selanjutnya adalah penentuan jenis elektroda dan ukuran yang akan digunakan serta posisi pengelasan yang sesuai dengan WPS (Welding Specification Procedure). Pada penelitian ini menggunakan kawat elektroda las AWS E-7018 dengan ukuran diameter $3,2 \mathrm{~mm}$ dan $4 \mathrm{~mm}$, dengan posisi las $1 \mathrm{G}$ (down hand).

Tabel 4. Detail Pengelasan

\begin{tabular}{|c|c|c|c|c|c|c|}
\hline \multicolumn{2}{|c|}{$\begin{array}{l}\text { Tebal } \\
\text { Pelat }\end{array}$} & $\begin{array}{c}\text { Diameter } \\
\text { Kawat }(\mathrm{mm})\end{array}$ & $\begin{array}{l}\text { Tegangan } \\
\text { (Voltage) }\end{array}$ & $\begin{array}{l}\text { Kec. Las } \\
(\mathrm{cm} / \mathrm{min})\end{array}$ & $\begin{array}{l}\text { Kec. rata-rata } \\
\text { Las }(\mathrm{cm} / \mathrm{min})\end{array}$ & $\begin{array}{c}\text { Masukan panas } \\
\text { (Heat Input) } \\
(\text { Joule/cm) }\end{array}$ \\
\hline \multirow{3}{*}{$8 \mathrm{~mm}$} & F1 & 3,2 & 25 & 15,20 & \multirow{3}{*}{14,53} & \multirow{3}{*}{258,09} \\
\hline & $\mathrm{F} 2$ & 3,2 & 25 & 14,40 & & \\
\hline & F3 & 3,2 & 25 & 14,00 & & \\
\hline \multirow{3}{*}{$8 \mathrm{~mm}$} & F1 & 3,2 & 25 & 15,30 & \multirow{3}{*}{14,97} & \multirow{3}{*}{250,50} \\
\hline & $\mathrm{F} 2$ & 4 & 25 & 15,10 & & \\
\hline & F3 & 4 & 25 & 14,50 & & \\
\hline \multirow{3}{*}{$\begin{array}{c}10 \\
\mathrm{~mm}\end{array}$} & F1 & 3,2 & 25 & 15,10 & \multirow{3}{*}{14,60} & \multirow{3}{*}{256,85} \\
\hline & $\mathrm{F} 2$ & 3,2 & 25 & 14,60 & & \\
\hline & F3 & 3,2 & 25 & 14,10 & & \\
\hline \multirow{3}{*}{$\begin{array}{c}10 \\
\mathrm{~mm}\end{array}$} & F1 & 3,2 & 25 & 15,90 & \multirow{3}{*}{15,10} & \multirow{3}{*}{248,34} \\
\hline & $\mathrm{F} 2$ & 4 & 25 & 14,80 & & \\
\hline & F3 & 4 & 25 & 14,60 & & \\
\hline
\end{tabular}

Keterangan:

$\mathrm{F} 1=$ Lapisan las pertama

F2 = Lapisan las kedua

F3 = Lapisan las ketiga

\subsection{Hasil Pengujian Tarik}

Tegangan tarik dapat didefinisikan sebagai perbandingan antara beban maksimum yang dicapai selama percobaan uji tarik dengan luas penampang batang mula-mula. Pengujian dilakukan dengan cara mencekam kedua sisi 
spesimen yang berlawanan arah sampai spesimen patah. Tujuan dari pengujian tarik adalah untuk mengetahui nilai kekuatan tarik rata-rata dan modulus elastisitas rata-rata dari suatu material. Sedangkan spesifikasi mesin yang digunakan adalah merk Shimadzu UH 1000kNI.

Pembuatan spesimen untuk pengujian dilakukan di bengkel bubut. Standar spesimen mengacu pada ASTM E8. Pengujian tarik dilakukan di UPTD Laboratorium Perindustrian LIK Takaru Tegal. Prosedur pelaksanaan uji yang pertama adalah dengan mengurus surat pengujian kepada kepala laboratorium setelah itu mengurus administrasi dan menunggu surat untuk pengujian, setelah mendapat surat untuk pengujian selanjutnya menunggu jadwal uji yang akan dilaksanakan. Sebelum spesimen diuji, dilakukan pengukuran spesimen menggunakan vernier caliper sebagai acuan perhitungan uji tarik.

Pada hasil pengujian tarik ini sudah dilakukan uji normalisasi data sehingga data yang didapatkan lebih baik dari data sebelum dilakukan uji normalisasi. Sedangkan data sesungguhnya atau sertifikat hasil pengujian dapat dilihat pada halaman lampiran.

Tabel 5. Data Hasil Pengujian Tarik

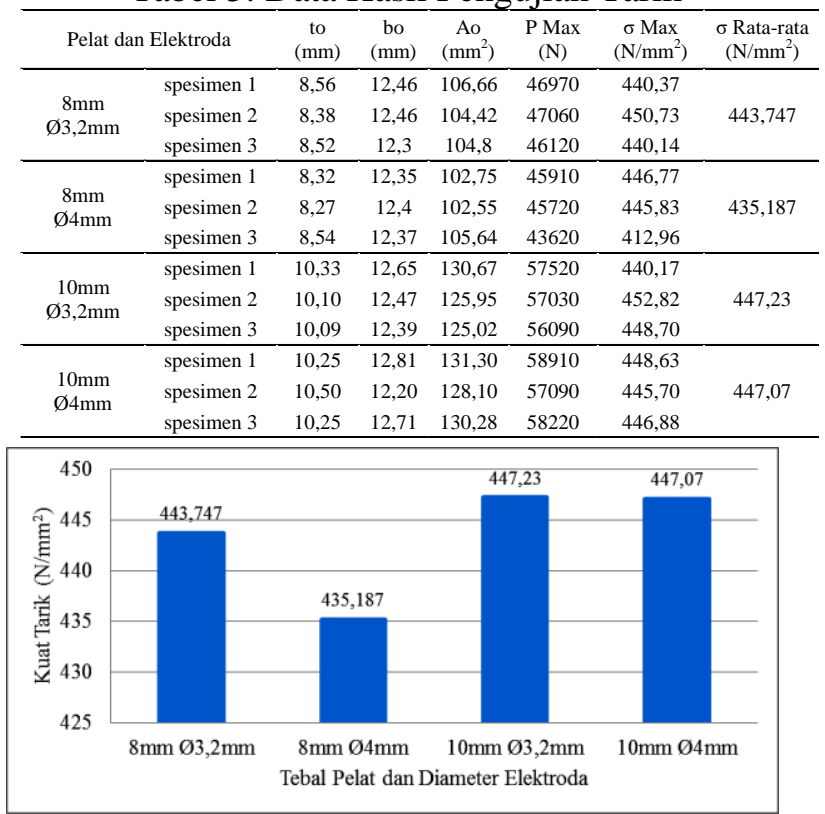

Gambar 4. Diagram Hasil Tegangan Tarik

Pada Tabel 5 nilai pada tebal pelat $8 \mathrm{~mm}$ dengan diameter elektroda $3,2 \mathrm{~mm}$ menurun sebesar $8,56 \mathrm{~N} / \mathrm{mm}^{2}$ ke diameter elektroda $4 \mathrm{~mm}$, dikarenakan hasil pengujian mengalami perpatahan pada daerah lasan. Sementara pada tebal pelat $10 \mathrm{~mm}$ dari diameter elektroda $3,2 \mathrm{~mm}$ ke diameter elektroda $4 \mathrm{~mm}$ mengalami penurunan kekuatan hanya sebesar $0,16 \mathrm{~N} / \mathrm{mm}^{2}$.
Batas tegangan tarik standar nilai pengujian sebesar $410 \mathrm{~N} / \mathrm{mm}^{2}$ (MPa).

\subsection{Regangan}

Merupakan perbandingan antara pertambahan panjang $(\Delta \mathrm{L})$ dengan panjang mula-mula. Regangan dapat dinyatakan dengan presentasi panjang dengan satuan persen (\%). Dinyatakan dengan rumus:

$$
e=\frac{L i-L_{0}}{L_{0}} \times 100 \%
$$

dimana Li adalah panjang sesudah patah (mm), Lo adalah panjang mula-mula $(\mathrm{mm})$ dan $e$ adalah regangan $(\%)$.

Tabel 6. Data Hasil Regangan

\begin{tabular}{ccccccc}
\hline \multirow{2}{*}{ Pelat dan Elektroda } & $\begin{array}{c}\text { Lo } \\
(\mathrm{mm})\end{array}$ & $\begin{array}{c}\mathrm{Li} \\
(\mathrm{mm})\end{array}$ & $\begin{array}{c}\Delta \mathrm{L} \\
(\mathrm{mm})\end{array}$ & $\begin{array}{c}\text { Regangan } \\
(\%)\end{array}$ & $\begin{array}{c}\text { Regangan } \\
\text { Rata-rata } \\
(\%)\end{array}$ \\
\hline \multirow{2}{*}{$8 \mathrm{~mm}$} & spesimen 1 & 50 & 62,79 & 12,79 & 25,58 & \\
$\varnothing 3,2 \mathrm{~mm}$ & spesimen 2 & 50 & 61,55 & 11,55 & 23,10 & 24,253 \\
& spesimen 3 & 50 & 62,04 & 12,04 & 24,08 & \\
\hline \multirow{2}{*}{$8 \mathrm{~mm} \emptyset 4 \mathrm{~mm}$} & spesimen 1 & 50 & 66,81 & 16,81 & 23,06 & \\
& spesimen 2 & 50 & 63,01 & 13,01 & 15,04 & 16,747 \\
& spesimen 3 & 50 & 64,75 & 14,75 & 12,14 & \\
\hline \multirow{2}{*}{$10 \mathrm{~mm}$} & spesimen 1 & 50 & 57,52 & 7,52 & 26,02 & \\
$\varnothing 3,2 \mathrm{~mm}$ & spesimen 2 & 50 & 56,07 & 6,07 & 29,50 & 27,80 \\
& spesimen 3 & 50 & 53,55 & 3,55 & 27,88 & \\
\hline \multirow{2}{*}{ 10mm } & spesimen 1 & 50 & 63,76 & 13,76 & 27,52 & \\
$\varnothing 4 \mathrm{~mm}$ & spesimen 2 & 50 & 63,30 & 13,30 & 26,60 & 26,173 \\
& spesimen 3 & 50 & 62,20 & 12,20 & 24,40 & \\
\hline
\end{tabular}

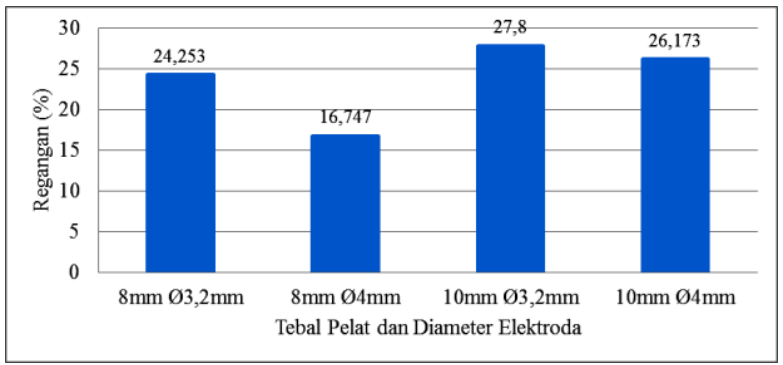

Gambar 5. Diagram Hasil Regangan

Nilai dari diagram hasil regangan pada masing-masing pelat sama-sama mengalami penurunan yaitu $7,506 \%$ pada pelat $8 \mathrm{~mm}$ dan $1,627 \%$ pada pelat $10 \mathrm{~mm}$. Batas regangan standar nilai pengujian sebesar $22 \%$.

\subsection{Modulus Elastisitas}

Modulus elastisitas sering disebut sebagai Modulus young yang merupakan perbandingan antara tegangan dan regangan aksial dalam deformasi yang elastis. Sehingga modulus elastisitas menunjukkan kecenderungan suatu material untuk berubah bentuk dan kembali lagi kebentuk semula bila diberi beban. 
Untuk hampir semua logam, pada tahap sangat awal dari uji tarik, hubungan antara beban atau gaya yang diberikan berbanding lurus dengan perubahan panjang bahan tersebut. Ini disebut daerah linier.

Modulus elastisitas dapat dirumuskan sebagai berikut:

$$
\mathrm{E}=\frac{\sigma}{e}
$$

dimana $\mathrm{E}$ adalah modulus elastisitas (MPa), $\sigma$ adalah tegangan maksimum $\left(\mathrm{MPa}, \mathrm{N} / \mathrm{mm}^{2}\right), e$ adalah regangan $(\%)$.

Tabel 7. Data Hasil Modulus Elastisitas

\begin{tabular}{|c|c|c|c|c|c|}
\hline \multicolumn{2}{|c|}{ Pelat dan Elektroda } & $\begin{array}{c}\sigma \mathrm{Max} \\
\left(\mathrm{N} / \mathrm{mm}^{2}\right)\end{array}$ & $\begin{array}{c}\text { Regangan } \\
(\%)\end{array}$ & $\begin{array}{c}E \\
\left(\mathrm{~N} / \mathrm{mm}^{2}\right)\end{array}$ & $\begin{array}{c}\text { E Rata-rata } \\
\left(\mathrm{N} / \mathrm{mm}^{2}\right)\end{array}$ \\
\hline \multirow{3}{*}{$\begin{array}{c}8 \mathrm{~mm} \\
\emptyset 3,2 \mathrm{~mm}\end{array}$} & spesimen 1 & 450,73 & 25,58 & 17,62 & \multirow{3}{*}{18,26} \\
\hline & spesimen 2 & 440,14 & 23,10 & 19,05 & \\
\hline & spesimen 3 & 436,18 & 24,08 & 18,11 & \\
\hline \multirow{3}{*}{$8 \mathrm{~mm} \emptyset 4 \mathrm{~mm}$} & spesimen 1 & 449,82 & 23,06 & 19,51 & \multirow{3}{*}{27,747} \\
\hline & spesimen 2 & 446,77 & 15,04 & 29,71 & \\
\hline & spesimen 3 & 412,96 & 12,14 & 34,02 & \\
\hline \multirow{3}{*}{$\begin{array}{c}10 \mathrm{~mm} \\
\emptyset 3,2 \mathrm{~mm}\end{array}$} & spesimen 1 & 417,70 & 26,02 & 16,05 & \multirow{3}{*}{15,857} \\
\hline & spesimen 2 & 455,29 & 29,50 & 15,43 & \\
\hline & spesimen 3 & 448,70 & 27,88 & 16,09 & \\
\hline \multirow{3}{*}{$\begin{array}{l}10 \mathrm{~mm} \\
\varnothing 4 \mathrm{~mm}\end{array}$} & spesimen 1 & 448,63 & 27,52 & 16,30 & \multirow{3}{*}{17,34} \\
\hline & spesimen 2 & 463,15 & 26,60 & 17,41 & \\
\hline & spesimen 3 & 446,88 & 24,40 & 18,31 & \\
\hline
\end{tabular}

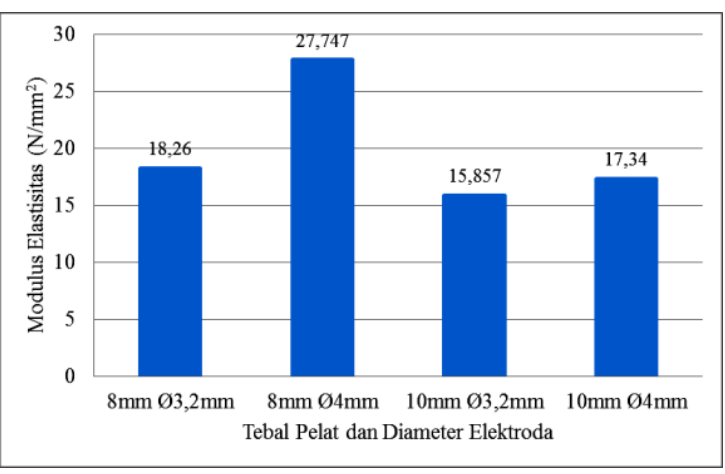

Gambar 6. Diagram Hasil Modulus Elastisitas

Nilai dari diagram diatas pada masingmasing pelat sama-sama mengalami kenaikan yaitu $9,487 \mathrm{~N} / \mathrm{mm}^{2}$ pada pelat $8 \mathrm{~mm}$ dan 1,483 $\mathrm{N} / \mathrm{mm}^{2}$ pada pelat $10 \mathrm{~mm}$. Batas MoE standar nilai pengujian sebesar $16-20 \mathrm{~N} / \mathrm{mm}^{2}(\mathrm{MPa})$.

\subsection{Tegangan Luluh}

Titik luluh merupakan suatu batas dimana material akan terus mengalami deformasi tanpa adanya penambahan beban. Tegangan (stress) yang mengakibatkan bahan menunjukkan mekanisme luluh ini disebut tegangan luluh (yield stress).
Tabel 8. Data Hasil Tegangan Luluh

\begin{tabular}{cccccc}
\hline \multicolumn{2}{c}{ Pelat dan Elektroda } & $\begin{array}{c}\text { Ao } \\
\left(\mathrm{mm}^{2}\right)\end{array}$ & $\begin{array}{c}\text { P Luluh } \\
(\mathrm{N})\end{array}$ & $\begin{array}{c}\sigma \text { Luluh } \\
\left(\mathrm{N} / \mathrm{mm}^{2}\right)\end{array}$ & $\begin{array}{c}\sigma \text { Luluh } \\
\text { Rata-rata } \\
\left(\mathrm{N} / \mathrm{mm}^{2}\right)\end{array}$ \\
\hline \multirow{2}{*}{ 8mm } & spesimen 1 & 106,66 & 31940 & 299,44 & \\
$\varnothing 3,2 \mathrm{~mm}$ & spesimen 2 & 104,42 & 31620 & 302,88 & 298,88 \\
& spesimen 3 & 105,96 & 31190 & 294,32 & \\
\hline \multirow{2}{*}{ 8mm } & spesimen 1 & 103,79 & 31970 & 308,01 & \\
$\varnothing 4 \mathrm{~mm}$ & spesimen 2 & 102,75 & 31810 & 309,60 & 306,737 \\
& spesimen 3 & 102,55 & 31030 & 302,60 & \\
\hline \multirow{2}{*}{ 10mm } & spesimen 1 & 130,67 & 38190 & 292,23 & \\
\hline \multirow{2}{*}{ 10mm } & spesimen 2 & 127,18 & 39090 & 307,38 & 298,523 \\
& spesimen 3 & 125,02 & 37000 & 295,96 & \\
& spesimen 1 & 128,10 & 39410 & 307,41 & \\
& spesimen 2 & 125,90 & 39410 & 312,99 & 309,387 \\
& spesimen 3 & 130,28 & 40090 & 307,76 & \\
\hline
\end{tabular}

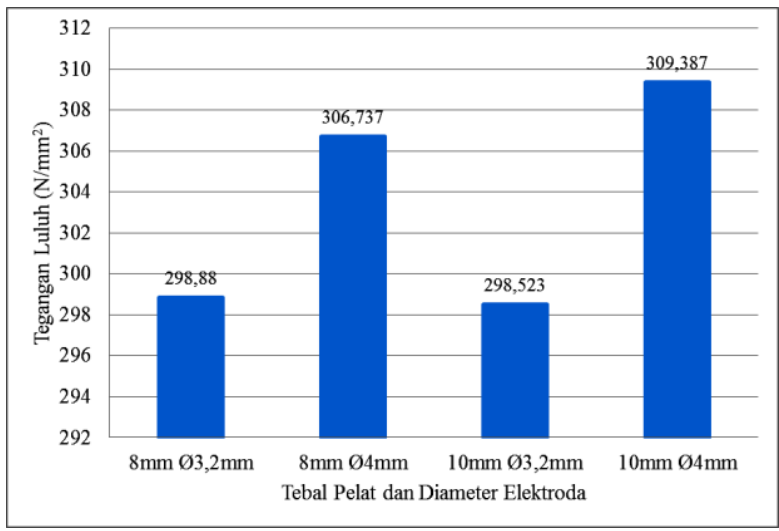

Gambar 7. Diagram Hasil Tegangan Luluh

Nilai dari diagram hasil tegangan luluh diatas pada masing-masing pelat sama-sama mengalami kenaikan yaitu $7,857 \mathrm{~N} / \mathrm{mm}^{2}$ pada pelat $8 \mathrm{~mm}$ dan $10,864 \mathrm{~N} / \mathrm{mm}^{2}$ pada pelat $10 \mathrm{~mm}$. Batas tegangan luluh standar nilai pengujian sebesar $275 \mathrm{~N} / \mathrm{mm}^{2}$ (MPa).

Dari diagram hasil pengujian tarik, dapat dianalisa bahwa nilai rata-rata dari tegangan tarik pada diameter elektroda $3,2 \mathrm{~mm}$ dengan tebal pelat $8 \mathrm{~mm}$ ke diameter elektroda $4 \mathrm{~mm}$ dengan tebal pelat $8 \mathrm{~mm}$ mengalami penurunan kekuatan yang cukup tinggi sebesar $8,56 \mathrm{~N} / \mathrm{mm}^{2}$ penurunan ini terlalu jauh, sehingga dapat disimpulkan bahwa penggunaan diameter elektroda $3,2 \mathrm{~mm}$ mempunyai kekuatan yang lebih tinggi dibanding diameter elektroda $4 \mathrm{~mm}$ pada pelat setebal $8 \mathrm{~mm}$. Sedangkan pada diameter elektroda $3,2 \mathrm{~mm}$ dengan tebal pelat $10 \mathrm{~mm}$ ke diameter elektroda 4 $\mathrm{mm}$ dengan tebal pelat $10 \mathrm{~mm}$ mengalami penurunan kekuatan $0,16 \mathrm{~N} / \mathrm{mm}^{2}$, sehingga dapat disimpulkan bahwa penggunaan diameter elektroda $3,2 \mathrm{~mm}$ mempunyai kekuatan yang lebih tinggi dibanding diameter elektroda $4 \mathrm{~mm}$ pada pelat setebal $10 \mathrm{~mm}$. Sehingga dapat ditarik analisa bahwa diameter elektroda 3,2 $\mathrm{mm}$ dengan tebal pelat $10 \mathrm{~mm}$ memiliki kekuatan tarik yang baik.

Pada keempat kasus hasil tarik, dapat dibandingkan dengan menganalisa dari hasil 
pengujian dengan melihat dari grafik yang telah dibuat dan mengamati patahan yang terdapat pada kedua variasi diameter elektroda, dilihat dari grafik pada keempat variasi regangan, modulus elastisitas dan tegangan luluh memiliki kesamaan dalam naik atau turunnya nilai dari diagram, yaitu sama-sama mengalami proses kenaikan dan penurunan pada kawat elektroda berdiameter 3,2 $\mathrm{mm}$ dan pada kawat elektroda berdiameter $4 \mathrm{~mm}$. Dalam kasus ini nilai regangan dari elektroda berdiameter $3,2 \mathrm{~mm}$ merupakan nilai tertinggi dibandingkan nilai dari elektroda berdiameter 4 $\mathrm{mm}$, sedangkan dalam nilai modulus elastisitas dan tegangan luluh dari kawat elektroda $4 \mathrm{~mm}$ merupakan nilai tertinggi dibandingkan dengan nilai dari kawat elektroda $3,2 \mathrm{~mm}$.

Gambar $8-9$ menunjukkan bahwa daerah patahan dari masing-masing pelat bervariasi, daerah perpatahan yang terletak di daerah las pada pelat $8 \mathrm{~mm}$ diameter elektroda $4 \mathrm{~mm}$ terdapat pada spesimen 2(B), 4(D) dan 5(E), sedangkan pada semua material uji patahan terletak pada daerah base metal. Hal ini menunjukkan bahwa kekuatan las pada pelat $8 \mathrm{~mm}$ diameter elektroda $4 \mathrm{~mm}$ merupakan penggunaan yang kurang baik digunakan untuk pengelasan dibandingkan dengan pengelasan yang lainnya, karena pada pelat 8 $\mathrm{mm}$ diameter elektroda $4 \mathrm{~mm}$ mengalami perlakuan panas yang lebih tinggi dibandingkan dengan kawat elektroda berdiameter $3,2 \mathrm{~mm}$. Sehingga dapat disimpulkan bahwa kawat elektroda berdiameter 3,2 $\mathrm{mm}$ merupakan kawat elektroda yang mempunyai kekuatan, keuletan dan ketangguhan paling tinggi.

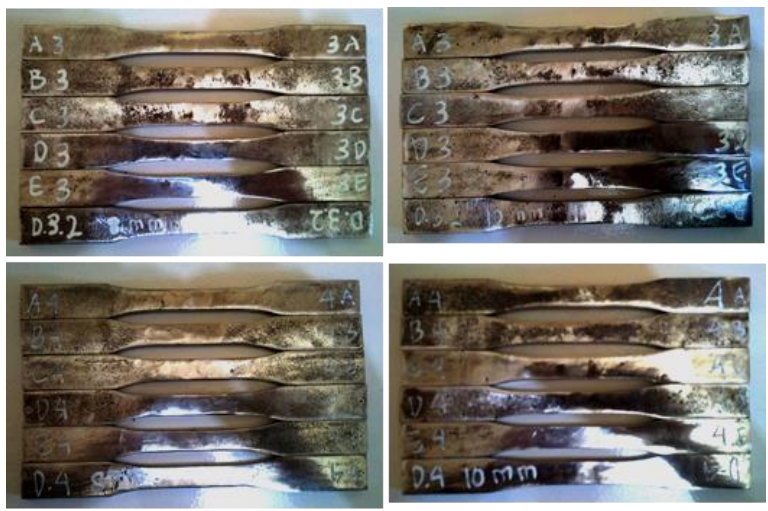

Gambar 8. Spesimen Sebelum Pengujian

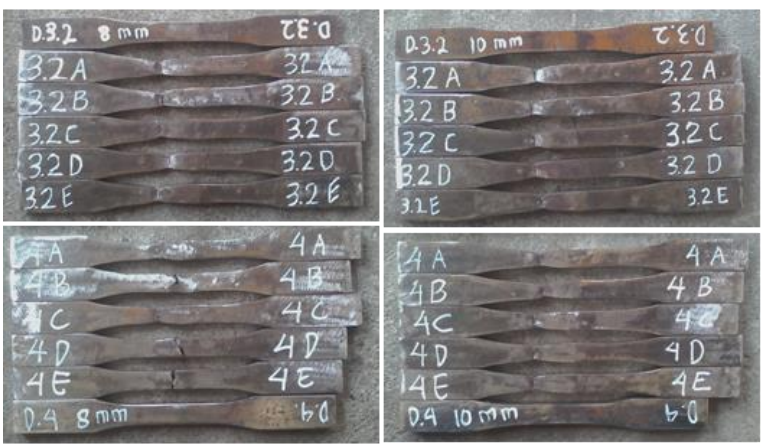

Gambar 9. Spesimen Setelah Pengujian

\subsection{Hasil Pengujian Impak}

Pengujian impak adalah suatu pengujian yang digunakan untuk menentukan sifat-sifat suatu material yang mendapatkan beban dinamis, sehingga dari pengujian ini dapat diketahui sifat ketangguhan suatu material baik dalam wujud liat maupun ulet serta getas. Tujuan dari pengujian impak adalah untuk mengetahui nilai energi impak rata-rata suatu material. Sedangkan spesifikasi mesin yang digunakan adalah merk Hung Ta HT-8041.

Standar spesimen mengacu pada ASTM E23. Pengujian impak dilakukan di UPTD Laboratorium Perindustrian LIK Takaru Tegal. Prosedur pelaksanaan uji yang pertama adalah dengan mengurus surat pengujian kepada kepala laboratorium setelah itu mengurus administrasi dan menunggu surat untuk pengujian, setelah mendapat surat untuk pengujian selanjutnya menunggu jadwal uji yang akan dilaksanakan. Sebelum spesimen diuji, dilakukan pengukuran spesimen menggunakan vernier caliper sebagai acuan perhitungan uji impak.
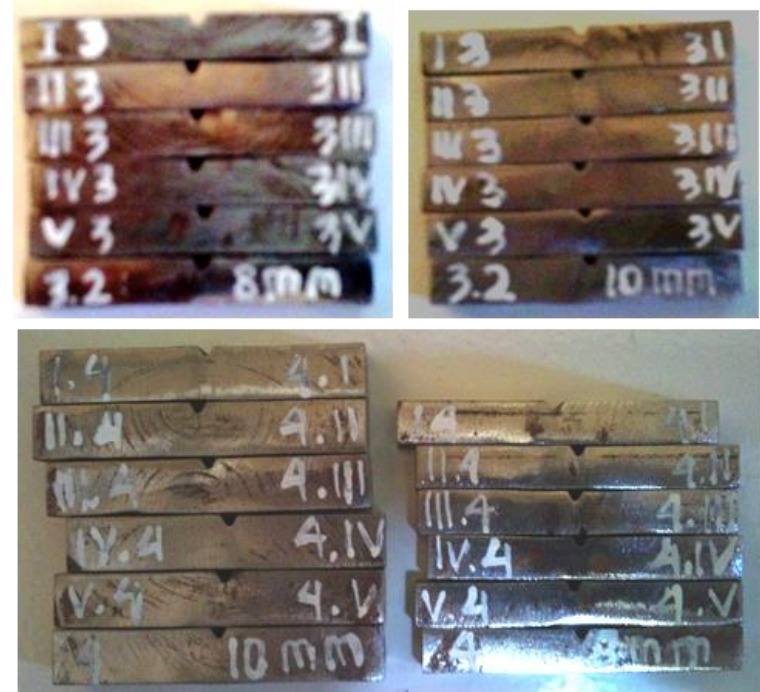

Gambar 10. Spesimen Sebelum Pengujian
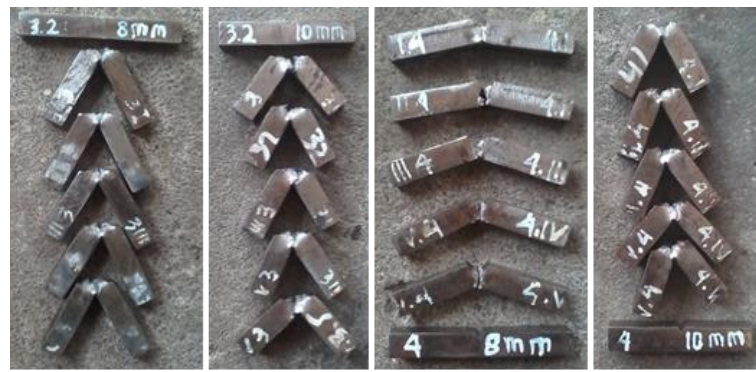

Gambar 11. Spesimen Setelah Pengujian 
Tabel 9. Data Hasil Pengujian Impak

\begin{tabular}{cccc}
\hline \multicolumn{2}{c}{ Pelat dan Elektroda } & $\begin{array}{c}\text { Energi Impak (KV) } \\
\text { (Joule) }\end{array}$ & $\begin{array}{c}\text { Energi Impak (KV) } \\
\text { Rata-rata (Joule) }\end{array}$ \\
\hline \multirow{2}{*}{$8 \mathrm{~mm}$} & spesimen 1 & 92,13 & \\
$\varnothing 3,2 \mathrm{~mm}$ & spesimen 2 & 92,13 & 90,67 \\
& spesimen 3 & 87,74 & \\
\hline \multirow{2}{*}{$8 \mathrm{~mm} \varnothing 4 \mathrm{~mm}$} & spesimen 1 & 38,44 & 44,91 \\
& spesimen 2 & 46,17 & \\
& spesimen 3 & 50,12 & 295,90 \\
\multirow{2}{*}{$10 \mathrm{~mm}$} & spesimen 1 & 292,88 & \\
$\varnothing 3,2 \mathrm{~mm}$ & spesimen 2 & 302,26 & 273,83 \\
& spesimen 3 & 292,56 & \\
\hline \multirow{2}{*}{$10 \mathrm{~mm}$} & spesimen 1 & 269,03 & \\
$\varnothing 4 \mathrm{~mm}$ & spesimen 2 & 278,63 & \\
& spesimen 3 & 273,84 & \\
\hline
\end{tabular}

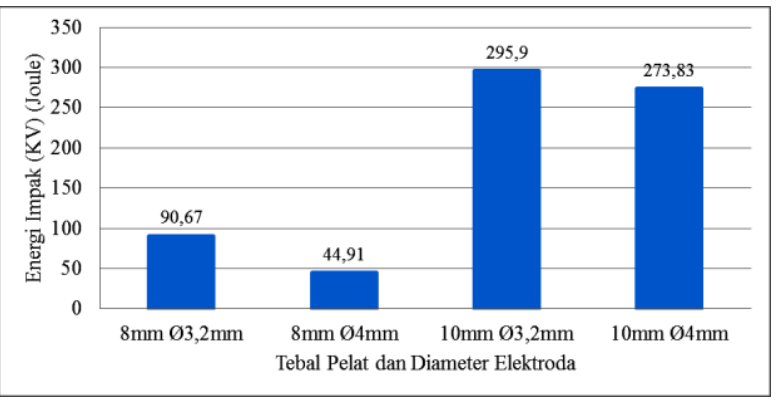

Gambar 12. Diagram Hasil Energi Impak

Dari Gambar 12 hasil pengujian impak, dapat dianalisa bahwa nilai rata-rata dari energi impak pada diameter elektroda $3,2 \mathrm{~mm}$ dengan tebal pelat $8 \mathrm{~mm}$ ke diameter elektroda $4 \mathrm{~mm}$ dengan tebal pelat $8 \mathrm{~mm}$ mengalami penurunan energi yang cukup besar 45,76 Joule penurunan ini terlalu jauh, sehingga dapat disimpulkan bahwa penggunaan diameter elektroda 3,2 $\mathrm{mm}$ mempunyai kekuatan impak yang lebih tinggi dibanding diameter elektroda $4 \mathrm{~mm}$ pada pelat setebal $8 \mathrm{~mm}$. Sedangkan pada diameter elektroda $3,2 \mathrm{~mm}$ dengan tebal pelat $10 \mathrm{~mm}$ ke diameter elektroda $4 \mathrm{~mm}$ dengan tebal pelat $10 \mathrm{~mm}$ mengalami penurunan energi impak sebesar 22,07 Joule, sehingga dapat disimpulkan bahwa penggunaan diameter elektroda $3,2 \mathrm{~mm}$ mempunyai kekuatan impak yang lebih tinggi dibanding diameter elektroda $4 \mathrm{~mm}$ pada pelat setebal $10 \mathrm{~mm}$. Penurunan energi impak diameter elektroda $3,2 \mathrm{~mm}$ ke diameter elektroda $4 \mathrm{~mm}$ pada pelat setebal $8 \mathrm{~mm}$ ini yang paling tinggi dibanding penggunaan variasi diameter elektroda yang ketebalan pelatnya setebal $10 \mathrm{~mm}$. Sehingga dapat ditarik analisa bahwa diameter elektroda 3,2 $\mathrm{mm}$ dengan tebal pelat $10 \mathrm{~mm}$ memiliki energi impak yang paling tinggi. Batas energi impak standar nilai pengujian sebesar $103 \pm 5,2$ Joule untuk ketebalan pelat $10 \mathrm{~mm}$, sedang pada pelat 8 mm sebesar 82,4 $\pm 5,2$ Joule.

\section{KESIMPULAN}

Hasil pengujian tarik didapatkan nilai tegangan tarik, tegangan luluh, modulus elastisitas serta nilai regangan lebih baik menggunakan diameter elektroda $3,2 \mathrm{~mm}$ pada masing-masing ketebalan pelat $8 \mathrm{~mm}$ dan $10 \mathrm{~mm}$. Dikarenakan pengaruh masukan panas yang terjadi, semakin besar diameter elektroda yang digunakan dalam pengelasan maka semakin besar pula masukan panas yang terjadi dan akan menyebabkan perubahan struktur pada daerah lasan atau Heat Affected Zone.

Hasil pengujian impak didapatkan nilai energi impak yang lebih baik digunakan adalah diameter elektroda $3,2 \mathrm{~mm}$ dari pada diameter elektroda $4 \mathrm{~mm}$ dari masing-masing pelat $8 \mathrm{~mm}$ dan $10 \mathrm{~mm}$.

\section{DAFTAR PUSTAKA}

[1] American Welding Society, Certification Manual for Welding Insfectors Fourth Edition, Miami : American Welding Society, 2000.

[2] ASTM E8/E8M-11. 2012. Standard Test Methods For Tension Testing Of Metallic Materials. USA.

[3] ASTM E23-07a. 2011. Standard Test Method For Notched Bar Impact Testing Of Metallic Materials. USA.

[4] AWS D 11 Committee on Structural Welding, AWS D1.1Structural Welding, Miami : American Welding Society, 2001.

[5] Jokosisworo, S., 2009, Pengaruh Besar Arus Listrik dengan Menggunakan Elektroda SMAW Terhadap Kekuatan Sambungan Las Butt Joint pada Plat Mild Steel.

[6] Kustrio P, 2015, Analisa Pengaruh Kuat Arus Pengelasan SMAW Terhadap Kekuatan Tarik Sambungan Pelat Baja Dengan Ketebalan Berbeda.

[7] Mulyatno, Imam Pujo \& Hartono, Y., 2008, Analisis Pengaruh Perlakuan Panas Terhadap Pelat klasifikasi BKI Tebal $10 \mathrm{~mm}$ Pada Sambungan Las.

[8] Sri Widharto. 2013. WELDING INSPECTION, Mitra Wacana Media, Jakarta.

[9] Sunaryo, Hery. 2008. Teknik Pengelasan Kapal Jilid 1 untuk Sekolah Menegah Kejuruan. Jakarta : Direktorat Pembinaan Sekolah Menengah Kejuruan.

[10] Sunaryo, Hery. 2008. Teknik Pengelasan Kapal Jilid 2 untuk Sekolah Menegah Kejuruan. Jakarta : Direktorat Pembinaan Sekolah Menengah Kejuruan. 